\title{
DESTINED FOR FAILURE: AMERICAN PROSPERITY IN THE AGE OF BAILOUTS.
}

Santa Barbara, CA: Praeger. 224 pages, 2010

by Sanchez, Nicolas, Christopher Kopp and Francis Sanzari

It is a pleasure to write a review of this book (by the way, this will be a very unorthodox book review, see below). Full disclosure here: Nick Sanchez is an old and dear friend, and a former colleague of mine when we overlapped, for six years, 1991-1997, as professors of economics at Holy Cross College.

One of my own contributions to student development is that I have co authored numerous refereed articles in scholarly journals with members of my undergraduate classes. Well, Nick has done me one better in this regard: this entire book is co-authored with two of his undergraduate students, Christopher Kopp and Francis Sanzari. This must surely be a rarity in publishing. Indeed, I know of no other case where a professor has co authored a full length book with undergraduates. I really regard this as a stupendous accomplishment. My own articles with students take up anywhere from 10 to 20 published pages; this is an entire book stretching on for 224 pages. These student co authors of his must be very exceptional young men.

As to the book itself, it will be a welcome one for Austro-libertarians, even though Sanchez is not himself a member of the praxeological school of economics. First and foremost in this regard is his brilliant Keynesian bashing.

Full stop. I am now no longer continuing to write a review of this book. True confession here: I wrote the previous sentence before I saw any Keynesian bashing in the book. At this point I started to look for some; I found very little. That is one of the reasons I stopped writing the review. In my defense, I am now unburdening my soul. Yes, sometimes, as in this case, I write before I know what I'm talking about. But, that was only a first draft. My critics may charge me with doing this in publications, too. However, as far as I am concerned, I really do try to clean up matters of this sort before going into print. So, as I say, I am now leaving off writing this book review.

Instead, gentle reader, I am now directly addressing you. Consider this a side note, off the topic of the book review, at least for the moment. I got this far in the book review, and I just couldn't continue. Hey, I told you that this would be an unorthodox book review! At this point, I wrote a letter to the main author of this book, Prof. Nick Sanchez. Here is that letter (a hint to those who might become

\footnotetext{
* Walter E. Block, Ph.D. is Harold E. Wirth Eminent Scholar Endowed Chair and Professor of Economics Joseph A. Butt, S.J. College of Business Loyola University New Orleans 6363 St. Charles Avenue, Box 15, Miller Hall 318 New Orleans, LA 70118, tel: (504) 864-7934, fax: (504) 864-7970 wblock@loyno.edu
} 
confused as to who is communicating, me or my now debating partner, Nick Sanchez, the author of this book; when I write, I indent my paragraphs, as above; when I transmit material written by Nick and sent to me, I do not indent paragraphs):

\section{Dear Nick:}

I started to write a review for your book. See attached. I had a very positive opening, and, then, I got stuck. I wanted to say, for the most part, nice things about your book, and, only, at the end, say something to the effect that not everyone can agree with everyone else on everything, and here are a few disagreements I have with the authors. And conclude by saying that despite these minor disagreements, I highly recommend the book.

But, in all honesty, I couldn't. I didn't realize how different your and my political economic philosophies. I'm an Austro libertarian; I've been called a free market fundamentalist, with good reason. I regard Milton Friedman as barely better than a commie; if I had to characterize your views, it would be that you are a Friedmanite; a very moderate supporter of free enterprise. You like Coase. I've written over a dozen articles criticizing as worse than a commie. I'm serious. Most of the people you regard as heroes I regard as villains. You never even mention any of the people I regard as heroes. I favor the entire elimination of the Fed, of public schooling, of government regulations such as anti trust. I see unions as criminal gangs virtually per se. I favor the entire separation of the state and health, welfare, education. Heck, I'm an anarchist, an anarcho capitalist. I reject the entire notion of "public goods." Thus, virtually all of my review would have been highly critical. There are only a few chapters on which I overlap with you.

Now, I'm still willing to write that review. But, I don't relish the thought of ripping into your book. I regard us as friends; you were my biggest supporter, by far, at Holly Cross. Why should I write a scathing review, the only honest review I can write? On the other hand, if you relish this sort of thing, I will write an eviscerating review.

Best regards,

Walter

And, dear reader, here is Nick Sanchez's response to my letter, interspersed with my responses to him, which are marked off by these marks: [[.

From: Nicolas Sanchez [mailto:nsanchez@holycross.edu]

Sent: Sunday, October 31, 2010 3:35 PM

To: Walter Block

Subject: RE: Book plus interview 
Hi, Walter, I am surprised that you do not find the book sufficiently pro-market, or even sufficiently close to your ideology. So, let me try to determine better where we disagree, going point by point:

1. We are against involvement in wars, making clear that governments are prone to get us into wars. The only war defended is the Second World War because there is no doubt that in that war we were attacked;

[[ This is not strictly true. On p. 124 you defend the North side of the War of 1861-1865, characterizing it as a "Civil War." But, a true civil war occurs when both sides of the altercation each want to rule the entire entity of which both, together, comprise. For example, the Spanish Civil War of 1936 was a true civil war, in that the Communists and the Fascists each wanted to rule over the entire country, Spain. In the War of Northern Aggression of 1861 (or the War to Prevent Southern Secession) only the North wanted control over the entire U.S. The South merely wanted to secede, something they had every right to do under the Constitution. Nor was this conflagration over slavery; this curious and horrible institution was in effect on both sides of the Mason Dixon line. Lincoln himself bruited it about that the war was to keep the union together; he aimed to do so with or without slavery. ${ }^{46} \mathrm{I}$ also favor the seceding side in another war of secession, the one sometimes called the Revolutionary War of the $18^{\text {th }}$ century, the colonies versus Great Britain.

[[ We also disagree about the so called World War II. As far as I am concerned, this was merely a continuation of the so-called World War I. In that event, the Allies and the Axis Powers were evenly matched. They were killing thousands of soldiers on each side over a scant few inches of territory in the trenches, from 1914-1917. Then the big bully boy U.S. government gratuitously entered the battle in 1917, tossing its weight on the British side, mainly because U.S. imperialists held more UK than German bonds. ${ }^{47}$ In the aftermath of this battle, the Treaty of Versailles placed sole blame on the Germans, and sought to punish this nation in a draconian manner (Carr, 1947; Cowling, 1975; Keynes, 1920). Cutting out the historical details, his lead to the German hyperinflation of 1923 (Evans, 2003), and, inevitably, to the rise of Hitler. Yes, the Japanese attacked us in Pearl Harbor, but this was because Roosevelt, who ran on a peace platform in 1940, goaded them into that action. ${ }^{48}$

[[ I also strenuously object to your characterization of present U.S. expenditures on the military as "defense." On your page 123 you repeat this mischaracterization

\footnotetext{
${ }^{46}$ For support of this claim, see Adams, 2000; DiLorenzo, 2002A, 2002B, Engerman, 1997; Gordon, 1998; Hummel, 1996; Rosenberg, 1972; Stromberg, 1979; Thornton and Ekelund, 2004, Woods, 2010. ${ }^{47}$ For readings on World War I revisionism, see: Barnes, 1929; 1972; Denson, 1997; Doenecke, 1979; Ferguson, 2000; Lee, 1963; Lutz, 1928; Martin, 1977; Polnar and Woods, 2008; Powell, 2005; Radosh and Rothbard, 1972; Raico, 1998; Rothbard, 1989; Taylor, 1972

48 For a bibliography on World War II revisionism, see: Barnes, 1966A, 1966B, 1972; Beard, 1946, 1948; Bernstein, 1968; Charmley, 1996; Davis, 1975; Denson, 1997; Doenecke, 1982, 1983, 1986; Grattan, 1939; Griswold, 1938; Klein, 1969; Lewis, 1972; Liggio Martin, 1976; Martin, 1963, 1977; Mills, 1976; Newman, 1993; Polnar and Woods, 2008; Raico, 1998; Rogerson, 1938; Robertson, 1971; Rothbard, 1972; Schroeder, 1958; Snell, 1962; Suvorov, 1990; Taylor, 1996 [1965]; Tolly, 2002; Utley, 1985.
} 
on numerous occasions. On your page 125 you do distinguish between "defense" and "offense," but do not carry through consistently on this distinction.

2. We are very critical of the current tax system, making it clear that people waste resources as they try to comply with very complex tax laws. We come out in favor of a combination of the fair tax and the flat tax. I thought you would find that acceptable.

[[ As a libertarian anarchist, or anarcho capitalist, I do not find any taxes "fair." I regard them all as theft. Not as akin to theft; but, rather, as outright and explicit theft. They are compulsory payments, so there is no other way to characterize them.

[[ Schumpeter $(1942,198)$ states: "The theory which construes taxes on the analogy of club dues or of the purchase of the services of, say, a doctor only proves how far removed this part of the social science is from scientific habits of mind."

[[ You state (p. 153): “... taxes are necessary and proper for life in an organized society." I am shocked, really shocked, that you would think that I "would find that acceptable." If you had cited and then tried to refute the anarcho-capitalist view of this matter, that would be one thing. Then, at least, you would do us the honor of trying to refute our position. But to totally ignore it, and then think this would be "acceptable" to an advocate of this position, is hard to understand. You mention (p. 153) "the creation and maintenance of public roads and highways" as a justification of taxes. Evidently, you are unfamiliar with my most recent book (Block, 2009) available here for free: http://mises.org/books/roads_web.pdf. In this publication I make the point that the government, the institution to which you want to assign this task, regularly murders some 40,000 on an annual basis on its statist roads. How could I possibly agree with you on this matter? You (p. 153) bewail the government's "inefficient collection mechanism." In contrast, I applaud this. Given that something is evil, I would vastly prefer that it be done inefficiently.

[[ I am not at all supportive of your call for a flat tax. Suppose I were offered a choice between a flat tax of $90 \%$, or a highly graduated one of this sort: earnings of less than $\$ 9,999$ per year, $1 \%$ income tax; $\$ 10,000$ - $\$ 99,999$ income, $2 \%$ tax; $\$ 100,000$ $\$ 1$ million, 3\% tax; more than $\$ 1$ million, 4\% tax. I would certainly prefer the latter to the former, even though it is a progressive tax. I would still prefer this even if we significantly increased the progressivity to, for example, earnings of less than $\$ 9,999$ per year, $1 \%$ income tax; $\$ 10,000-\$ 99,999$ income, $4 \%$ tax; $\$ 100,000$ - $\$ 1$ million, $8 \%$ tax; more than $\$ 1$ million, $16 \%$ tax.

3. We come out strongly against labor unions in Detroit and also in the educational sector

[[ Yes, this cannot be denied. You do indeed pummel unions, some of them, but on very narrow grounds: they have insisted upon gigantic wage increases, and thus

\footnotetext{
${ }^{49}$ For a fuller defense of the anarchist libertarian position, see Anderson and Hill, 1979; Benson, 1989 , 1990; Block, 2007, 2010, forthcoming; DiLorenzo, 2010; Hasnas, 1995; Higgs, 2009; Hoppe, 2008; King, 2010; Kinsella, 2009; Long, 2004; Molyneux, undated; Murphy, 2005; Rothbard, 1973, 1998; Stringham, 2007; Tannehill, 1984; Tinsley, 1998-1999.
} 
endangered their industries. But your indictment of unionism is a very limited one; you do not demonstrate that these boosts in wages are unwarranted. You do not attack them philosophically, as the illicit economic tape worms that they necessarily are. You do not criticize them all as per se illicit, criminal organizations. ${ }^{50}$ You do not at all call for criminal sanctions against them, as would a libertarian.

[[ I am of course very sympathetic with the title of your chapter that deals with this matter: "American Unions: Robin Hoods or White-Collar Criminals?" I was looking, in vain, for the latter conclusion. On pp. 94-95 you come close to the libertarian position, but it eludes you. You state: “... we must reduce, restrict, or eliminate the coercive powers of collective bargaining. There are a number of ways to do produce such an outcome, including the limitation of union size, impositions of restrictions on collective bargaining, or, most radically, the prohibition of unions altogether." But the key to illicit union power is that their threat is not limited to mass walkouts. Restricting their "ability to participate in the political process (p. 95), imposing right to work laws (p. 96) as you urge, are simply incompatible with libertarian law.

4. We come out strongly against government intervention in the financial sector (which led to a housing catastrophe) and also against intervention in the insurance markets (which led to the bad outcomes during Katrina);

[[ I regard your chapter 7 on housing as among your best. You get things half right. You make a good case against Fannie, Freddie, HUD, NINJA loans, CRA, etc. ${ }^{51}$ But, you entirely miss the other half, the Austrian part of the story, which is based on artificially low rates of interest, leading to overinvestment in long term capital and consumer goods, such as, preeminently, housing. ${ }^{52}$

50 The text somewhat overstates the matter. It is logically possible for unions to be legitimate under libertarian law, if they strictly limited their repertoire to mass walkouts. For an explication of this, see Baird, 1990, 2000; Block, 1984, 1991, 1996A, 1996B, 2010; Evans and Block, 2002; Heldman, 1977; Heldman, Bennett and Johnson, 1981; Hutt, 1973, 1989; Petro, 1957; Reynolds, 1984, 1987, 2009; Schmidt, 1973; Shea, 2010; Rothbard, 1993

51 You were preceded on this exact point by Liebowitz, 2008A, 2008B, 2008C, Liebowitz and Day, 1998, who you do not cite.

${ }^{52}$ For readings on the Austrian Business Cycle Theory (ABCT), see Garrison, 2001; Hayek, 1931; Mises, 1912, 1949; Rothbard, 1975, 1993. For Austrian predictions of this crisis see: Blumen, 2005; DeCoster, tba; Economics of contempt, 2008; Englund, 2004; Mayer, 2003; Murphy, 2007, 2008; Paul, 2002; Schiff, Undated A, Undated B, Undated C, Undated D, 2006, 2007; Shostak, 2003, 2005; Thornton, 2004, 2009, Undated. Stated Paul, "The special privileges granted to Fannie and Freddie have distorted the housing market by allowing them to attract capital they could not attract under pure market conditions. As a result, capital is diverted from its most productive use into housing. This reduces the efficacy of the entire market and thus reduces the standard of living of all Americans. Despite the long-term damage to the economy inflicted by the government's interference in the housing market, the government's policy of diverting capital to other uses creates a short-term boom in housing. Like all artificially created bubbles, the boom in housing prices cannot last forever. When housing prices fall, homeowners will experience difficulty as their equity is wiped out. Furthermore, the holders of the mortgage debt will also have a loss. These losses will be greater than they would 
[[ In the view of the ferocious battle that Austrians have been having with Krugman regarding ABCT (Murphy, 2008A, 2008B, 2008C. 2008D, 2009A, 2009B, 2009C, 2009D, 2010A, 2010B), I find rather unsettling your positive reliance (p. 118) on Krugman (2008).

5. We are against government regulation of the nuclear power industry;

[[ I cannot find anywhere in your book where you explicitly oppose government regulation of the nuclear power industry. However, we are in full agreement with regard to your support for this source of energy.

6. We make it clear that decreases in taxes without similar decreases in government expenditures will not work because of Ricardian equivalence;

[[ Yes, yes, government deficits create problems (Buchanan and Wagner, 1977). But, consider the following two scenarios. A: Taxes, $90 \%$ of the GDP; expenditure, 90\% of the GDP; no deficit. B: Taxes, 5\% of the GDP, expenditures, $6 \%$ of the GDP, deficit, 1\% of the GDP. Would you join me in preferring the latter? Not on the basis of what you say immediately above.

7. Throughout the book we emphasize that unless markets are allowed to have competitive prices, the markets will not work efficiently;

[[ This, to be sure, cannot be denied. However, we have markedly different views as to what constitutes a "competitive price." In your perspective, as a neoclassical economist, this depends, intimately, on the number of competitors in an industry. If there is only one, you would characterize this as a "monopoly." In my estimation, in contrast, as an Austrian economist," the number of firms in an industry, the concentration ratio, the Herfendahl Index, are entirely irrelevant. As I see matters, the definition of an "industry" it totally arbitrary. Instead, the sole issue is, does the government prevent entry? If so, there is monopoly, no matter how many companies there $\operatorname{are}^{54}$; if not, there are single sellers, but no untoward monopoly. ${ }^{55}$

[[ In very sharp contrast indeed, you state (p. 191): “...(this) ... does not mean

have otherwise been had government policy not actively encouraged overinvestment in housing." (I thank the following people for helping me put together this list: Robert P. Murhpy, Madhusudan Raj, Koen Swinkels, Washington Sanchez, John Robinson). Here are Austrian responses to critics of ABCT: Anderson, 2009A, 2009B, Barnett and Block 2005, 2006A, 2006B, 2008; Block, 2001; Block and Barnett, 2007; Cochran, Call, and Glahe, 1999; Cochran and Call, 1998; Cochran and Glahe, 1994; Cochran, 1998, 2001A, 2001B, 2001C 2003, 2009; Gunning, 1985; Murphy, 2008A, 2008B, 2008C, 2009A, 2009B, 2009C; Raj, 2008; Ritenour, 2000; Salerno, 1989, 1996. 1999, 2000; Sechrest, 1998; Woods, 2009A, 2009B

${ }^{53}$ For a bibliography of the Austrian analysis of competition and monopoly, and thus anti trust, see: Anderson, et. al., 2001; Armentano, 1999; Block, 1977, 1994; Block and Barnett, 2009; Boudreaux and DiLorenzo, 1992; Costea, 2003; DiLorenzo, 1997; DiLorenzo and High, 1988; High, 1984-1985; McChesney, 1991; Rothbard, 2004; Shugart, 1987; Smith, 1983; Tucker, 1998A, 1998B

${ }^{54}$ There are numerous taxi cab firms in New York City.

${ }_{55} \mathrm{IBM}$ and Alcoa were for a time single sellers, but not monopolists. 
that government regulations are out of place within a market economy; in fact, government regulations can improve resource efficiency. This can be done, for example, when monopolies are either regulated or banned, when collusion among firms is prohibited... Regrettably, competitive markets are never perfect because they normally require a large number of firms to participate in these markets. ${ }^{, 56}$ This is about as far apart from the Austrian theory of monopoly as it is possible to be. The Praxeological school entirely rejects this distinction between perfect and imperfect competition.

8. We support solutions to environmental problems based on the introduction of private property rights;

[[ I find myself greatly out of sympathy for this chapter 9 of yours, dealing with these issues. I reject the notion of "negative externalities." Rather, with Rothbard (1982), I see the issue in terms of the government allowing, supporting, subsidizing, the trespass of smoke and dust particles onto other people's property. This is a government failure, not a market failure. ${ }^{57}$

[[ I also vociferously reject your reliance on, of all people, Coase, as support for your supposedly private property rights oriented analysis of environmental issues. As far as I am concerned, this economist is worse than the Communists on the issue of private property. At least the latter had a theory on this issue: property belongs, properly, to the proletariat. Coase, in contrast, has a vacuum instead of a theory of property rights. In his view, property properly belongs to whomever its ownership will most enhance GDP. I regard this as an abnegation of private property rights, since every time relative prices change, so will ownership. ${ }^{58}$ For Coase, rightful ownership is a meaningless term.

[[ I have a real disagreement with you over your use of the term "rent seeking" (p. 142). Why use so innocuous a phrase as "rent," to indicate what is essentially

\footnotetext{
${ }^{56}$ In this passage (p. 191) you also call for government regulation " ... when firms are forced to absorb the externalities that they impose on others (e.g., pollution)..." This, too, is greatly at variance from libertarian analysis. Here, it is the government that is responsible for the problem, by first seizing control of law, and then promoting pollution. For a refutation of this view of yours, see Rothbard, 1982, which in my view is the best thing ever written on the so called external diseconomy of pollution.

57 There is no such thing in my view. Rothbard's $(1997,178)$ reductio absurdum of public goods is as follows: " $\mathrm{A}$ and $\mathrm{B}$ often benefit, it is held, if they can force $\mathrm{C}$ into doing something. . . . [A]ny argument proclaiming the right and goodness of, say, three neighbors, who yearn to form a string quartet, forcing a fourth neighbor at bayonet point to learn and play the viola, is hardly deserving of sober comment."

For more on this see Barnett and Block, 2007, 2009; Block, 1983, 2000, 2003; Bibliography, undated; Cowen, 1988; De Jasay, 1989; Holcombe, 1997; Hoppe, 1989; Hummel, 1990; Osterfeld, 1989; Pasour, 1981; Rothbard, 1985, 1997; Schmidtz, 1991; Sechrest, 2003, 2004A, 2004B, 2007.

${ }^{58}$ Here are some Austro libertarian criticisms of the infamous Coase theorem: Block (1977, 1995, 1996, 2000, 2003, 2006, 2010, forthcoming, unpublished A, unpublished B), Block, Barnett and Callahan (2005), Barnett and Block (2007, 2009), Cordato (1989, 1992a, 1992b, 1997, 1998, 2000), Hoppe (2004), Krause (1999), Krecke (1996), Lewin (1982), North (1990, 1992, 2002), Rothbard (1982), Stringham and White (2004) and Terrell (1999)
} 
theft? (Block, 2000). Nor can I see my way clear to support your call (p. 140) for "individual fishing quotas (ITQs)." I am opposed, bitterly so, to "market-based" (pp. 140, 141) schemes such as ITQs, tradable emissions rights (TERs) ${ }^{59}$ and Friedmanite school vouchers. ${ }^{60}$ What is so wrong with full private property rights, as in the ocean, rivers, lakes, stream and seas? ?1 $^{61}$ After all, we do not have "individual housing quotas," nor "individual automobile quotas," nor yet "individual shoe quotas." Why, then, should we be content with "individual fishing quotas?" And, why should only "... a majority of the federal government's land holdings ... be privatized" (emphasis added, p. 143)? Why not return all of it to the private sector, where it belongs? (Minor error in this chapter; it is the Kuznets curve, not Kuznet, on p. 148).

9. Finally, on a more positive note, the whole book emphasizes that technical change, savings and well functioning markets are the keys to economic growth. We openly reject Keynesian economics.

[[You do indeed say (p. 192) "...that the authors of this work view Keynesian economics as a burden to understanding..." However, I also see the following: "Keynes also came up with the brilliant concept of a marginal propensity to consume ... (p. 186); "If one were to know the marginal propensity to consume plus the behavior of firms and governments, then total output in the economy can be not only predicted but also manipulated (p. 187); “... it would take extraordinary circumstances (e.g., wars, crash in asset values) for consumers to alter their predicted behavior. Therefore, the economy is driven by investment and government expenditures" (p. 188). None of this has anything to do with what I regard as the correct analysis of these issues, namely, ABCT. And, as far as I can see matters, Friedman is a, get ready for this, I hope you are sitting down, a Keynesian.

[[ You also write: "There were several main challenges to the early Keynesian approach. In the 1950s, Milton Friedman..." (p. 188). But, I see Friedman as a Keynesian. Skousen (2001) states: "This slide from Keynesian theory to particular policies was well illustrated in his seventh edition (1967), when Samuelson cited a statement by Milton Friedman, 'We are all Keynesians now.' However, at the end of chapter 11, Samuelson (7: 210) then referenced the full quotation from a 1966 interview of Friedman in Time magazine: "As best I can recall it, the context was: "In one sense, we are all Keynesians now; in another nobody is any longer a Keynesian." Friedman (1968, p. 15) would later put it this way: "We all use the Keynesian language and apparatus, none of us any longer accepts the initial Keynesian conclusions." ${ }^{62}$

[[ But, surely, the "language and apparatus" are more important, far more important, in determining the categorization of an economist's views, than are any

\footnotetext{
${ }^{59}$ McGee and Block, 1994.

${ }^{60}$ Rockwell, 1998, 2000, 2002; Rome and Block. 2006; Rothbard, 1971, 1994. 1995; Salisbury, 2003; Vance, 1996; Yates, 2002a, 2002b; Young and Block. 1999.

${ }^{61}$ Block, 1992; Motichek, Block and Johnson, 2008; Whitehead, and Block. 2002; Whitehead, Gould and Block. 2004.

${ }^{62}$ Also see on this: Block, 1999, fn. 16, Garrison, 2010; Gillis, 2003; Samuelson, 1967, 210; 1970, 193.
} 
particular conclusions. The way I see matters, the Keynesians tend more toward fiscal policy, and the Friedmanians toward monetary policy, but, both sets of dismal scientists adhere to the hydraulic theory, according to which aggregate demand and aggregate supply determine economic patterns. Only the Austrians differ on this matter.

[[ In contrast, I see you as a Friedmanite Keynesian. You state (p. 195): “... the government must create sufficient amounts of money to maintain wage and price stability; the experience of the Great Depression, when the government decreased the money supply significantly ... cannot be repeated. Nominal wage decreases of significant amounts are not in anyone's interest." If this is not Friedman speaking, channeled by Ben Bernanke, I don't know what it is. This is certainly incompatible with the Austrian analysis (Rothbard, 1975) of the events of the 1930s.

Walter, all of these points, I would think, are similar to those you would support--am I wrong on this? I will grant you that you have been critical of Coase's theorem, but it is used to point out that resources should go to those who are willing to pay the most for them, not whether Coase was right or wrong in his analysis.

[[ I don't at all buy into the Coasean notion that "resources should go to those who are willing to pay the most for them." Rather, they should stay with their rightful owners (a concept very alien to Coase, and, now, unhappily, it would appear, to you too). Of course, if I own an item, and I want to sell it, and you are willing to pay the most for it, then, of course, with my permission, it should go to you. However, if you and I are having a dispute over the ownership of a picture of you and your family, or your family heirlooms, then, even if I am willing to pay more for these things than you, it should certainly not go to me. Rather, the judge should give them to you. The Coasean judge, and, now, you, unfortunately, as a supporter of this truly evil man, would award your property to me, just because I am "willing to pay the most for them." This is entirely unjust, another word simply not in the Coasean lexicon. Nick, I simply cannot believe you have fallen this horrendous doctrine. But, your book indicates that you have, as do your follow up comments, above.

I have no clue where you get the impression that I have ever supported Friedman's ideas! With regard to public goods, I am currently writing a second book on this topic, and I argue that the existence of public goods can be used to support a much more conservative agenda than people realize. My personal feelings on public goods is that the subject has been hijacked to support a liberal agenda--but I will grant you that this discussion is missing from the current book. Hence my theoretical chapter does include public goods to make the point that my arguments (which are quite conservative, as expressed in points 1 through 9 above) are fully within the tradition of standard economics. I fully understand your frustration that we do not make much out of the Austrian viewpoint--EXCEPT that we do make a lot out of information problems in the economy, and that perspective is tied to the work of Hayek.

[[ You are an avid supporter of Friedman's analysis of the Great Depression. Decrease in the money supply (actually, stock), indeed. We differ widely on public 
goods. You accept this notion, I reject it. Yes, your views are "conservative," and "fully within the tradition of standard economics." That is the precise objection I have to them. I am a libertarian, not a conservative; I am an Austrian economist, and thus reject "standard economics." You certainly do discuss information, but not at all from a Hayekian perspective.

So, just for my personal knowledge, please explain to me how we differ on points 1 through 9 above, because I am really baffled. I do understand your objection to the issue of public goods and to not mentioning the Austrian tradition (even though it is embedded all over the place, and in particular chapter 2 which addresses crucial information problems).

[[ Austrian economics is not embedded throughout your book. It is totally absent.

But please feel free to be critical of the book. I hope you would mention, however, the points of agreement. We have been friends because I value highly your honesty and insights. At this point, I find it hard to understand why you would be so critical, but there is always room for learning. You do remain my friend no matter what. Best, Nick

[[ I hope and trust our friendship will survive this highly critical review. Based on the six years we spent together at Holy Cross (1991-1997), I am sure it will.

[[ Nick had also, previously, sent me this letter, which I also now repeat:

From: Nicolas Sanchez [mailto:NSANCHEZ@holycross.edu]

Sent: Monday, September 27, 2010 12:31 PM

To: Walter Block

Subject: Book plus interview

Dear Walter, I sent you a copy of my book last week=

I wanted to bring to your attention my most recent interview in the press, see below, which I think captures the whole idea of the book. It can be found at: http://www.wbjournal.com/news47411.html

You have been a great friend. Thanks for everything. Nick

[[ Here is Nick Sanchez's interview:

If you're at all in doubt of economic policies coming from Washington, D.C., then you'll likely be a fan of Nicolás Sánchez, a professor of economics at the College of Holy Cross in Worcester, who recently published a book entitled, "Destined for Failure: American Prosperity in the Age of Bailouts." His co-authors on the book, which is available on Amazon.com, were two Holy Cross seniors: Christopher Kopp of Hamburg, N.Y., and Francis Sanzari of West Hartford, Conn. Here, Sánchez discusses why Keynesian economics should be dropped by policymakers in favor of what's known as growth-theory economics. 
>> One of the things you point out in the book is the problem with China's currency being so under-valued. What's the solution to that problem? Is it tariffs?

It's not necessarily a tariff, but it has to made absolutely clear to the Chinese that this behavior is not going to be accepted. What I am talking about is saying to China that if they subsidize their production we will impose taxes on their imports. I want to make it very clear that I am very much in favor of competitive markets. But what the Chinese have been doing is not competition because they have been manipulating the foreign exchange rate.

[[ I am horrified, simply horrified, that you come out in favor of protectionism and tariffs. The Smoot - Hawley tariff of the 1930s threw our economy into a tailspin; we certainly do not need anything of the sort nowadays. Here, I fully agree with Milton Friedman: we should unilaterally declare full free trade with all nations, and stop these quasi, semi, demi, market-based (sneer) "free trade" agreements with other nations, such as NAFTA. If China wants to send us her goods and bargain basement prices, why should we object? In any case, the U.S. with Bernanke's QE1 and QE2 is doing exactly the same thing: lowering the value of the already very battered dollar.

>> What do you think of Bernanke's comments about the economy and the measures the Federal Reserve has taken?

Everything Bernanke has been saying has been tied up to Keynesian economics. Bernanke's solution to our economic problems is to make sure our interest rates are extremely low. But that creates disequilibrium. You may say, Well, the business community likes low interest rates, and I will say, Yes because they are thinking of themselves as individuals. They are not thinking of themselves as a community. The Wall Street Journal reported that very low interest rates have allowed companies that would otherwise have gone under because they are not competitive to remain in the market. Interest rates are too low, which allows certain companies that would have gone under to survive.

[[ Very good. I fully agree. I would only add that we should all support Ron Paul's (2010) effort to "End the Fed." But, I go further than that. I would really like to see criminal charges brought against Benny the Paper Hanger.

>> Aren't current policies about protecting jobs? And without them, wouldn't there have been very severe pain for America, at least in the short-term?

Our American economy doesn't work because firms survive. Our American economy works because there are new companies that come in, with technological advancements and then the technological advancements create the new jobs. We're running the economy based upon politics, but we're not running the economy based 
upon how the economy actually works.

[[ I of course favor new technology. However, this is not the essence of (limited) U.S. economic success. Rather, it is due to the vestiges of private property rights and free enterprise we still enjoy. This underlies our limited technological progress.

\section{>> If you had two minutes with the president, what would you say?}

I would say fire all the advisors who did not see what was coming. And the reason for that is because their models are based upon Keynesian models.

[[ I would urge him to resign. Or, to immerse himself in Austro libertarian literature. Better yet, to appoint Ron Paul as his Vice President (at least as of 2012), and, right now, do everything that Congressman Paul suggested.

[[ And now, for my response to Nick's letters to me:

\section{Dear Nick:}

Ok, I will write the book review. But, it won't be pretty. I'll certainly cover the points you mention in my review.

Best regards,

Walter

[[ Ok, ok, this is now me writing, once again; please pay attention, won't you. I hope and trust, gentle reader, that you are still following what I am saying. If not, please start again at the top. I apologize for the unorthodoxy of this review, but complicated circumstances make for a complicated book review. As you can, I have now finished the book review I started, and then interrupted with this correspondence between me and the author. Only, now, instead of confining my remarks to a review of his book, I have also taken into account his letters to me, and the interview he did about his book.

\section{Bibliography}

Adams, Charles. 2000. When in the Course of Human Events: Arguing the Case for Soutbern Secession. Lanham, Mass.: Rowman \& Littlefield.

Anderson, Terry and Hill, P.J. 1979. "An American Experiment in AnarchoCapitalism: The Not So Wild, Wild West," Journal of Libertarian Studies, 3: 9-29; http://mises.org/journals/jls/3_1/3_1_2.pdf

Anderson, William L. 2009. "Friedman and the Fed: Is Liquidity the Answer?" April 17; http://mises.org/story/2929

Anderson, William L. 2009. "One Cheer for Paul Krugman, or Why the Bubble Economy?" 
Anderson, William, Walter Block, Thomas J. DiLorenzo, Ilana Mercer, Leon Snyman and Christopher Westley. 2001. "The Microsoft Corporation in Collision with Antitrust Law," The Journal of Social, Political and Economic Studies, Vol. 26, No. 1, Winter, pp. 287-302

Armentano, Dominick T. 1999. Antitrust: The Case for Repeal. Revised $2^{\text {nd }}$ ed., Auburn AL: Mises Institute

Austrians who predicted housing bubble

Baird, Charles. 1990. "American Union Law: Sources of Conflict," Journal of Labor Research, Summer, pp. 269-292

Baird, Charles. 2000. "Unions and Antitrust," The Journal of Labor Research, Fall, pp. 585-600.

Barnes, Harry Elmer, ed. 1966B. Perpetual War for Perpetual Peace: A Critical Examination of the Foreign Policy of Franklin Delano Roosevelt and Its Aftermath. Westport, Conn.: Greenwood Publishing Group.

Barnes, Harry Elmer. 1929. The Genesis of the World War and Introduction to the Problem of War Guilt. New York: Alfred A. Knopf.

Barnes, Harry Elmer. 1966A. "A. J. P. Taylor and the Causes of World War II," New Individualist Review, Spring, pp. 3-16.

Barnes, Harry Elmer. 1972. In Quest of Truth and Justice: De-Bunking the War Guilt Myth. Colorado Springs, Colo.: Ralph Myles

Barnes, Harry Elmer. 1972. Pearl Harbor After a Quarter of a Century. New York: Arno Press.

Barnett, William II and Walter Block. 2005. "Professor Tullock on Austrian Business Cycle Theory," Advances in Austrian Economics, Vol. 8, pp. 431-443

Barnett, William II and Walter Block. 2006A. "On Gallaway and Vedder on Stabilization Policy" Quarterly Journal of Austrian Economics. Vol. 9, No. 1, spring, pp. 57-81; http://www.mises.org/journals/qjae/pdf/qjae9_1_5.pdf

Barnett, William and Walter Block. 2006B. "Tyler Cowen on Austrian Business Cycle Theory: A Critique." New Perspectives on Political Economy, Vol. 2, No. 2, pp. 26-84; http://pcpe.libinst.cz/nppe/2_2/nppe2_2_2.pdf; http://pcpe.libinst.cz/nppe/

Barnett, William II and Walter Block. 2007. "Coase and Van Zandt on Lighthouses," Public Finance Review, Vol. 35, No. 6, November, pp. 710-733

Barnett, William II and Walter Block. 2008. "Reply to Hummel on Austrian Business Cycle Theory." Reason Papers Vol. 30, Fall, pp. 59-90; http://www.reasonpapers.com/pdf/30/rp_30_4.pdf

Barnett, William and Walter Block. 2009. "Coase and Bertrand on Lighthouses," Public Choice; 140(1-2):1-13, http://dx.doi.org/10.1007/s11127-008-9375-x

Beard, Charles A. 1946. American Foreign Policy in the Making, 1932-1940: A Study in Responsibilities. New Haven: Yale University Press. 
Beard, Charles A. 1948. President Roosevelt and the Coming of the War, 1941: A Study in Appearances and Realities. New Haven: Yale University Press.

Benson, Bruce L. 1989. Enforcement of Private Property Rights in Primitive Societies: Law Without Government," The Journal of Libertarian Studies, Vol. IX, No. 1, Winter, pp. 1-26; http://mises.org/journals/jls/9_1/9_1_1.pdf

Benson, Bruce L. 1990. "Customary Law with Private Means of Resolving Disputes and Dispensing Justice: A Description of a Modern System of Law and Order without State Coercio,n The Journal of Libertarian Studies, Vol. IX, No. 2," pp. 25-42; http://mises.org/journals/jls/9_2/9_2_2.pdf

Bernstein, Barton J., ed. 1968. Towards a New Past: Dissenting Essays in American History. New York: Pantheon Books.

Bibliography. Undated. http://www.googlesyndicatedsearch.com/u/Mises $? h \mathrm{l}=$ en\&submit.x $=0 \&$ submit. $\mathrm{y}=0 \& \mathrm{q}=$ public $\% 20$ goods

Block, Walter E. Unpublished A. "Rejoinder to Boettke on Coasean Economics and Communism."

Block, Walter E. Unpublished B. "Rejoinder to Bertrand on lighthouses."

Block, Walter. 1977A. "Austrian Monopoly Theory -- a Critique," The Journal of Libertarian Studies, Vol. I, No. 4, Fall, pp. 271-279.

Block, Walter. 1977B. "Coase and Demsetz on Private Property Rights," The Journal of Libertarian Studies: An Interdisciplinary Review, Vol. I, No. 2, 1977, pp. 111-115; http://www.mises.org/journals/jls/1_2/1_2_4.pdf

Block, Walter. 1983. "Public Goods and Externalities: The Case of Roads," The Journal of Libertarian Studies: An Interdisciplinary Review, Vol. VII, No. 1, Spring, pp. 134; http://www.mises.org/journals/jls/7_1/7_1_1.pdf

Block, Walter. 1984. Book review of John Anderson and Morley Gunderson, Union-Management Relations in Canada, Don Mills, Ontario: Addison-Wesley Publishers, 1982; in The Journal of Labor Research, Vol. V, No. 1, Winter, pp. 103-105.

Block, Walter. 1991. "Labor Relations, Unions and Collective Bargaining: A Political Economic Analysis," Journal of Social Political and Economic Studies, Vol. 16, No. 4, Winter, pp. 477-507.

Block, Walter. 1994. "Total Repeal of Anti-trust Legislation: A Critique of Bork, Brozen and Posner, Review of Austrian Economics, Vol. 8, No. 1, pp. 35-70.

Block, Walter. 1995. "Ethics, Efficiency, Coasean Property Rights and Psychic Income: A Reply to Demsetz," Review of Austrian Economics, Vol. 8, No. 2, 1995, pp. 61-125; http://www.mises.org/journals/rae/pdf/rae8_2_4.pdf;

Block, Walter. 1996A. "Labor Market Disputes: A Comment on Albert Rees' 'Fairness in Wage Distribution,'" Journal of Interdisciplinary Economics, Vol. 7, No. 3, pp. 217-230

Block, Walter. 1996B. "Comment on Richard B. Freeman's 'Labor markets and institutions in economic development,"' International Journal of Social Economics, Vol. 23, No. 1, pp. 6-16 
Block, Walter 1996C. "O.J.'s Defense: A Reductio Ad Absurdum of the Economics of Ronald Coase and Richard Posner," European Journal of Law and Economics, Vol. 3, pp. 265-286

Block, Walter. 1999. "The Gold Standard: A Critique of Friedman, Mundell, Hayek, Greenspan," Managerial Finance, Vol. 25, No. 5, pp. 15-33; http://giorgio.emeraldinsight.com/vl $=4558845 / \mathrm{cl}=18 / \mathrm{nw}=1 / \mathrm{rpsv} / \mathrm{cw} / \mathrm{www} /$ mcb/03074358/contp1-1.htm; http://www.mises.org/etexts/goldcritique.pdf; http://141.164.133.3/faculty/Block/Blockarticles/goldstandard.htm】

Block, Walter. 2000A. "Watch Your Language," February 21; http://www.mises.org/fullarticle.asp?control=385\&month=17\&title=Watch+ Your+Language\&id=19; http:// mises.org $/$ daily $/ 385$

Block, Walter. 2000B. "Private Property Rights, Erroneous Interpretations, Morality and Economics: Reply to Demsetz," Quarterly Journal of Austrian Economics, Vol. 3, No. 1, Spring, pp. 63-78; http://www.mises.org/journals/qjae/pdf/qjae3_1_8.pdf;
Block,
Walter.
2000C.
"Word
Watch,"
April
20 ;

http://www.mises.org/fullstory.asp?control=414\&FS=Word+Watch

Block, Walter. 2001. "Yes, We Have No Chaff: A Reply to Wagner's "Austrian Business Cycle Theory: Saving the Wheat While Discarding the Chaff," Quarterly Journal of Austrian Economics, Vol. 4, No. 1, Spring, pp. 63-73. //www.mises.org/journals/qjae/pdf/qjae4_1_4.pdf

Block, Walter. 2003A. "Private property rights, economic freedom, and Professor Coase: A Critique of Friedman, McCloskey, Medema and Zorn," Harvard Journal of Law and Public Policy, Vol. 26, No. 3, Summer, pp. 923-951

Block, Walter. 2003B. "National Defense and the Theory of Externalities, Public Goods and Clubs." The Myth of National Defense: Essays on the Theory and History of Security Production, Hoppe, Hans-Hermann, ed., Auburn: Mises Institute, pp. 301334; http://www.mises.org/etexts/defensemyth.pdf

Block, Walter. 2006. "Coase and Kelo: Ominous Parallels and Reply to Lott on Rothbard on Coase," Whittier Law Review, Vol. 27, No. 4, pp. 997-1022

Block, Walter. 2007. "Anarchism and Minarchism; No Rapprochement Possible: Reply to Tibor Machan," Journal of Libertarian Studies, Vol. 21, No. 1, Spring, pp. 9199; http://www.mises.org/journals/jls/21_1/21_1_5.pdf

Block, Walter. 2009. The Privatization of Roads and Highways: Human and Economic Factors, Auburn, AL: The Mises Institute; http://mises.org/books/roads_web.pdf

Block, Walter. 2010A. "Are unions criminal gangs?” Global Virtue Ethics Review, Vol. 6. No. 1, pp. 28-49; http://www.spaef.com/article.php?id=1176; http://www.spaef.com/file.php?id=1176

Block, Walter E. 2010B. "A Response to Brooks' Support of Demsetz on the Coase Theorem." Dialogue, Vol. 2; http://www.unisvishtov.bg/dialog/2010/2.10.WB.pdf

Block, Walter. Forthcoming A. "Rejoinder to Machan on Anarchism and limited statism." Journal of Libertarian Studies 
Block, Walter. Forthcoming B. "Rejoinder to Brooks on Coase and Demsetz." Quarterly Journal of Austrian Economics

Block, Walter and William Barnett II. 2007A. "The Austrian Tent? A Rejoinder to Gallaway and Vedder" Corporate Ownership \& Control, Vol. 4, No. 3, p. 232; http://www.virtusinterpress.org/additional_files/journ_coc/issues/COC_Volume_ 4_Issue_3_Spring_2007_Continued).pdf

Block, Walter and William Barnett, II. 2007B. "On Laidler on Austrian Business Cycle Theory." Review of Austrian Economics, Vol. 20, No. 1, March, pp. 43-61; http://dx.doi.org/10.1007/s11138-006-0004-y

Block, Walter and William Barnett. 2009. "Monopsony Theory." American Review of Political Economy June/December, Vol. 7(1/2), pp. 67-109; http://www.arpejournal.com/ARPEvolume7number1-2/Block-Barnett.pdf; http://www.arpejournal.com/

Block, Walter, William Barnett II and Gene Callahan. 2005. "The Paradox of Coase as a Defender of Free Markets," NYU Journal of Law \& Liberty, Vol. 1, No. 3, pp. 1075-1095; http://tinyurl.com/2hbzd4; to be reprinted in Mario Rizzo, ed. forthcoming. Austrian Law and Economics

Block, Walter E. and Michael Fleischer. 2010. "How Would An Anarchist Society Handle Child Abuse?" October 13; http://www.lewrockwell.com/block/block167.html

Blumen, Robert. 2005. "Housing Bubble: Are We There Yet?." May 8; http://blog.mises.org/3566/housing-bubble-are-we-there-yet/

Boudreaux, Donald J., and DiLorenzo, Thomas J. 1992. "The Protectionist Roots of Antitrust," Review of Austrian Economics, Vol. 6, No. 2, pp. 81-96

Buchanan, James M. and Richard E. Wagner. 1977. Democracy in Deficit: The Political Legacy of Lord Keynes. Indianapolis: the Liberty Fund

Carr, 1947; Cowling, 1975; Keynes, 1920.

Carr, E.H. 1947. International Relations Between the Wars. New York: Macmillan. T

Charmley, John. 1996. Churchill's Grand Alliance: The Anglo-American Special Relationship, 1940-1957. New York: Harvest Books.

Cochran, John P. 1998. "Review of Central Banking in Theory and Practice, Alan S. Blinder, Cambridge and London: The MIT Press, 1998." Quarterly Journal of Austrian Economics, vol.1, no. 4 (winter), pp. 89-92. http://mises.org/journals/qjae/pdf/Qjae45.pdf

Cochran, John P. 2001A. "Hayek's Law and Rothbard's Wisdom." www.mises.org. August 22. http://mises.org/daily/765

Cochran, John P. 2001B. "The Hangover Theory?" March 16. http://mises.org/daily/630

Cochran, John P. 2003. "False Hopes, False Fears, and Real Concerns." Daily Article at http://www.mises.org ; June 17. http://www.mises.org/fullstory.asp?control=1249. 'Reprinted' at gold-eagle.com as http://www.gold-eagle.com/gold_digest_03/cochran061803.html. 
Cochran, John P. 2009. "Return of the Dead Hand"." Daily Article at http://www.mises.org; June 24. 2009. http://mises.org/story/3516

Cochran, John P. and Call, Steven T. 1998. "The Role of Fractional Reserve Banking and Financial Intermediation in the Money Supply Process: Keynes and the Austrians." The Quarterly Journal of Austrian Economics. 1(3): 29-40. http://mises.org/journals/qjae/pdf/Qjae33.pdf .

Cochran, John P. and Call, Steven T. 2001C. "Austrian Business Cycles, Plucking Models, and Real Business Cycles." Ludwig Von Mises Institute Working Paper. http://mises.org/journals/scholar/Cochran.pdf .

Cochran, John P. and Glahe, Fred R. 1994. "The Keynes-Hayek Debate: Lessons for Contemporary Business Cycle Theorists." History of Political Economy 26(1), Spring: 69-94. Reprinted in Wood, John ed. 2004. Friedrich A. von Hayek: Critical Assessments of Contemporary Economists, $2^{\text {nd }}$ Series Vol. II. Routledge, pp. 60-82; http://hope.dukejournals.org/cgi/reprint/26/1/69 .

Cochran, John P., Call, Steven T., and Glahe, Fred R. 1999. "Credit Creation or Financial Intermediation? Fractional Reserve Banking in a Growing Economy." The Quarterly Journal of Austrian Economics, vol. 2, no. 3, 53-64. http://mises.org/journals/qjae/pdf/Qjae2_3_2.pdf

Cordato, Roy E. 1989. "Subjective Value, Time Passage, and the Economics of Harmful Effects," Hamline Law Review, Vol. 12, No. 2, Spring, pp.229-244.

Cordato, Roy E. 1992a. "Knowledge Problems and the Problem of Social Cost" Journal of the History of Economic Thought, vol.14, Fall, pp. 209-224.

Cordato, Roy E. 1992b. Welfare Economics and Externalities in an Open-Ended Universe: A Modern Austrian Perspective, Boston: Kluwer.

Cordato, Roy E. 1997. "Market-Based Environmentalism and the Free Market: They're Not the Same," The Independent Review, Vol. 1, No. 3, Winter, pp. 371-386.

Cordato, Roy. 1998. "Time Passage and the Economics of Coming to the Nuisance: Reassessing the Coasean Perspective," Campbell Law Review, vol. 20, No. 2, Spring, pp. 273-292

Cordato, Roy. 2000. "Chasing Phantoms in a Hollow Defense of Coase" The Review of Austrian Economics, Vol. 13, No. 2, September, pp. 193-208.

Costea, Diana. 2003. "A Critique of Mises's Theory of Monopoly Prices." The Quarterly Journal of Austrian Economics. Vol. 6, No. 3, Fall, pp. 47-62; http://www.mises.org/journals/qjae/pdf/qjae6_3_3.pdf

Cowen, Tyler, ed. 1988. The Theory of Market Failure: A Critical Examination, Fairfax, VA: George Mason University Press; http://www.amazon.com/Theory-Market-FailureCritical-Examination/dp/0913969133/ref=sr_1_1?ie=UTF8\&s=books\&qid=12001914 $09 \& s r=1-1$

Cowling, Maurice. 1975. The Impact of Hitler: British Politics and British Policy, 1933-1940. Cambridge: Cambridge University Press.

Davis, Joseph S. 1975. The World Between the Wars, 1919-39: An Economist's View. Baltimore: Johns Hopkins University Press 
De Coster, Karen. tba

De Jasay, Anthony. 1989. Social Contract, Free Ride: A Study of the Public Goods Problem. Oxford University Press; http://www.amazon.com/Social-Contract-FreeRide-Paperbacks/dp/0198239122/ref=sr_1_1?ie=UTF8\&s=books\&qid=1200191531 $\& s r=1-1$

Denson, John V., ed. 1997. The Costs of War: America’s Pyrrhic Victories. New Brunswick, N.J.: Transaction Publishers

DiLorenzo, Thomas J. 1996. "The Myth of Natural Monopoly," Review of Austrian Economics, Vol. 9, No. 2, pp. 43-58; http://www.mises.org/journals/rae/pdf/rae9_2_3.pdf

DiLorenzo, Thomas J. 2002A. "The Consolidation of State Power via Reconstruction: 1865-1890," Journal of Libertarian Studies, Vol. 16, No. 2, Spring, pp. 139-161; http://mises.org/journals/jls/16_2/16_2_6.pdf

DiLorenzo, Thomas J. 2002B. The Real Lincoln: A New Look at Abrabam Lincoln, His Agenda, and an Unnecessary War. Roseville, Calif.: Prima Publishing.

DiLorenzo, Thomas J. 2010. "The Culture of Violence in the American West: Myth versus Reality." The Independent Review, v. 15, n. 2, Fall 2010, pp. 227-239; http://www.independent.org/pdf/tir/tir_15_02_4_dilorenzo.pdf

DiLorenzo, Tom and Jack High. 1988. "Antitrust and Competition, Historically Considered," Economic Inquiry, Vol. 26, No. 1, pp. 423-435, July.

Doenecke, Justus D. 1982. "Edwin M. Borchard, John Bassett Moore, and Opposition to American Intervention in World War II," The Journal of Libertarian Studies, Vol. VI, No. 1, Winter, pp. 1-34; http://mises.org/journals/jls/6_1/6_1_1.pdf

Doenecke, Justus D. 1983. "The Literature of Isolationism, 1972-1983: A Bibliographical Guide," The Journal of Libertarian Studies, Vol. VII, No. 1, Winter, pp. 157-184; http://mises.org/journals/jls/7_1/7_1_10.pdf

Doenecke, Justus D. 1986. "Explaining the Antiwar Movement, 1939-1941: The Next Assignment," The Journal of Libertarian Studies, Vol. VIII No. 1, Winter, pp. 139162; http://mises.org/journals/jls/8_1/8_1_10.pdf

Doenecke, Justus. 1979. "The Isolationist as Collectivist: Lawrence Dennis and the Coming of World War II," The Journal of Libertarian Studies, Vol. 3, No. 2, Summer, pp. 191-208; http://mises.org/journals/jls/3_2/3_2_6.pdf

Economics of contempt. 2008. "The Unofficial List of Pundits/Experts Who Were Wrong on the Housing Bubble." July 16; http://economicsofcontempt.blogspot.com/2008/07/official-list-of-punditsexpertswho.html

Engerman, Stanley L. 1997. "Review of the book Emancipating Slaves, Enslaving Free Men: A History of the American Civil War by Jeffrey Rogers Hummel," The Independent Review, Vol. II, No. 1, Summer, pp. 129-132. 
Englund, Eric. 2004. "Monetizing Envy and America's Housing Bubble.” July 19; http://www.lewrockwell.com/englund/englund13.html

Evans, Jason and Walter Block. 2002. "Labor Union Policies: Gains or Pains?" Cross Cultural Management, Vol. 9, No. 1, pp. 71-79

Evans, Richard J. 2003. The Coming of the Third Reich, Allen Lane

Ferguson, Niall. 2000. The Pity of War: Explaining World War I. New York, NY: Basic Books

Fox, Glenn. 2007. "The real Coase theorems" Cato Journal, Vol. 27, No. 3, Fall, pp. 373-396; http://www.cato.org/pubs/journal/cj27n3/cj27n3-5.pdf

Garrison, Roger W. 2001. Time and Money: The Macroeconomics of Capital Structure. London: Routledge; an important contribution to Austrian business cycle theory

Garrison, Roger W. 2010. "Is Milton Friedman a Keynesian?" January 27; http://mises.org/daily/4067

Gillis, Malcolm. 2003. "Economics and The Chicago School: Yesterday, Today and Tomorrow. March $18 . \quad$ Rice University; http://www.professor.rice.edu/professor/031820031.asp?SnID=325297287

Gordon, David, ed. 1998. Secession, State and Liberty. New Brunswick, N.J.: Transaction Publishers.

Government Interventions, Not Laissez Faire, Caused the Financial Crisis;" The Freeman, Vol. 59, Issue, 2, March; http://www.thefreemanonline.org/featured/did-deregulated-derivativescause-the-financial-crisis /

Grattan, C.H. 1939. The Deadly Parallel. Mechanicsburg, Penn.: Stackpole Books

Griswold, A. Whitney. 1938. The Far Eastern Policy of the United States. New York: Harcourt, Brace

Gunning, J. Patrick. (1985) "Causes of Unemployment: The Austrian Perspective." History of Political Economy. 17 (2): 222-244.

Hasnas, John. 1995. "The myth of the rule of law." Wisconsin Law Review 199; http://faculty.msb.edu/hasnasj/GTWebSite/MythWeb.htm

Hayek, Friedrich A. 1931. Prices and Production, London: Routledge.

Heinrich, David J. 2010. "Justice for All Without the State." The Libertarian Standard. May 6; http://www.libertarianstandard.com/articles/david-jheinrich/justice-for-all-without-the-state/

Heldman, Daniel C. 1977. American Labor Unions: Political Values and Financial Structure, Council on American Affairs, Washington D.C.

Heldman, Daniel C., James T. Bennett, and Manuel Johnson. 1981. Deregulating Labor Relations, Fisher Institute, Dallas.

Higgs, Robert. 2009. "Why We Couldn't Abolish Slavery Then and Can't Abolish Government Now." August 20; http://www.lewrockwell.com/higgs/higgs128.html

High, Jack. 1984-1985. "Bork's Paradox: Static vs Dynamic Efficiency in Antitrust Analysis," Contemporary Policy Issues, Vol. 3, pp. 21-34. 
Holcombe, Randall. 1997. "A Theory of the Theory of Public Goods," Review of Austrian Economics, Vol. 10, No. 1: 1-10; http://www.mises.org/journals/rae/pdf/RAE10_1_1.pdf

Hoppe, Hans-Hermann. 1989. "Fallacies of the Public Goods Theory and the Production of Security," The Journal of Libertarian Studies, Vol. IX, No. 1, Winter, pp. 27-46; http://www.mises.org/journals/jls/9_1/9_1_2.pdf

Hoppe, Hans-Hermann. 2004. "The Ethics and Economics of Private Property." October 11; http://www.lewrockwell.com/hoppe/hoppe11.html

Hoppe, Hans-Hermann. 2008. "Reflections on the Origin and the Stability of the State." June 23; http://www.lewrockwell.com/hoppe/hoppe18.html

Hummel, Jeffrey. 1990. "National Goods vs. Public Goods: Defense, Disarmament and Free Riders," The Review of Austrian Economics, Vol. IV, pp. 88-122; http://www.mises.org/journals/rae/pdf/rae4_1_4.pdf

Hummel, Jeffrey Rogers. 1996. Emancipating Slaves, Enslaving Free Men: A History of the American Civil War. Chicago: Open Court Publishing Company.

Hutt, W. H. 1973. The Strike Threat System: The Economic Consequences of Collective Bargaining, New Rochelle, N.Y.: Arlington House; http://www.amazon.com/exec/obidos/tg/detail/-/0870001868/lewrockwell/104$7552446-8407165$.

Hutt, W. H. 1989. "Trade Unions: The Private Use of Coercive Power," The Review of Austrian Economics, Vol. III, pp. 109-120; http://www.mises.org/journals/rae/pdf/rae3_1_7.pdf.

January 1; http://mises.org/story/3275

Keynes, John M. 1920. Economic Consequences of the Peace. New York: Harcourt Brace

King, Seth. 2010. "Daily Anarchist Interviews Walter Block," September 9; http://www.lewrockwell.com/block/block165.html

Kinsella, Stephan. 2009. "The Irrelevance of the Impossibility of AnarchoLibertarianism." August 20; http://www.stephankinsella.com/2009/08/20/theirrelevance-of-the-impossibility-of-anarcho-libertarianism/

Klein, B.J. 1969. Germany's Economic Prepartion for War. Cambridge, Mass.: Harvard University Press.

Krauss, Michael. 1999. "Tort Law, Moral Accountability, and Efficiency: Reflections on the Current Crisis" Markets and Morality, Vol. 2, No. 1, Spring; http://www.acton.org/publicat/m_and_m/1999_spr/krauss.html

Krecke, Elisabeth. 1996. "Law and the Market Order: An Austrian Critique of the Economic Analysis of Law," Journal des Economistes et des Etudes Humaines 7(1), March, pp.19-37; Commentaries on LaweשEconomics, 1997 Yearbook, ed., Robert W. McGee, pp.86-109.

Krugman, Paul. 2008. The Return of Depression Economics and the Crisis of 2008. New York: W.W. Norton. 
Lee, Dwight E., ed. 1963. The Outbreak of the First World War: Who Was Responsible? Lexington, Mass.: D.C. Heath

Lewin, Peter. 1982. "Pollution Externalities: Social Cost and Strict Liability." Cato Journal, vol. 2, no. 1, Spring, pp. 205-229.

Lewis, William R., ed. 1972. The Origins of the Second World War: A.J.P. Taylor and His Critics. New York: John Wiley \& Sons.

Liebowitz, Stan J. and Theodore E. Day. 1998. "Mortgage Discrimination in Boston: Where's the Bias?" Economic Inquiry, January 1998, pp.1-27; http://www.utdallas.edu/ liebowit/mortgage/mortgages.pdf

Liebowitz, Stan J. 2008A. "The real scandal: how feds invited the mortgage mess," New York Post, February 5;

Liebowitz, Stan J. 2008B. "Anatomy of a Train Wreck: Causes of the Mortgage Meltdown," Independent Policy Report, Independent Institute, October

Liebowitz, Stan J. 2008C. "The real scandal: how feds invited the mortgage mess." The New York Post, April 21; http://www.nypost.com/seven/02052008/postopinion/opedcolumnists/the_real_s candal_243911.htm?page $=0$

Liggio, Leonard P. and James J. Martin, eds. 1976. Watershed of Empire: Essays on New Deal Foreign Policy. Colorado Springs, Colo.: Ralph Myles.

Long, Roderick. 2004. "Libertarian Anarchism: Responses to Ten Objections" http://www.lewrockwell.com/long/long11.html

Lutz, Hermann. 1928. Lord Grey and the World War. New York: Alfred Knopf.

Martin, James J. 1963. American Liberalism and World Politics, 1931-1941: Liberalism's Press and Spokesmen on the Road Back to War Between Mukden and Pearl Harbor, 2 Vols. New York: Devin-Adair Publishers.

Martin, James J. 1977A. "Pearl Harbor: Antecedents, Background and Consequences," from The Saga of Hog Island: And Other Essays in Inconvenient History. Colorado Springs: Ralph Myles.

Martin, James J. 1977B. “The Saga of Hog Island, 1917-1921: The Story of the First Great War Boondoggle," from The Saga of Hog Island: And Other Essays in Inconvenient History. Colorado Springs: Ralph Myles.

Mayer, Chris. 2003. The Housing Bubble." The Free Market. Volume 23, Number 8 August; http://mises.org/freemarket_detail.aspx?control=450\&sortorder=articledate

McChesney, Fred. 1991. "Antitrust and Regulation: Chicago's Contradictory Views," Cato Journal, Vol. 10.

McGee, Robert W. and Walter Block. 1994. "Pollution Trading Permits as a Form of Market Socialism and the Search for a Real Market Solution to Environmental Pollution," Fordham University Law and Environmental Journal, Vol. VI, No. 1, Fall, pp. 51-77; http://www.walterblock.com/publications/pollution_trading_permits.pdf

Mills, C. Wright. 1976. Causes of World War II. Westport, Conn.: Greenwood Press. 
Mises, Ludwig von. [1912] 1953. The Theory of Money and Credit [originally published in German in 1912]. New Haven, CT: Yale University Press.

Mises, Ludwig von. [1949] 1998. Human Action, Scholars' Edition. Auburn: Mises Institute; http://www.mises.org/humanaction/chap17sec5.asp

Molyneux, Stefan. "The Stateless Society: An Examination of Alternatives," http://www.mail-

archive.com/libertarianenterprise@yahoogroups.com/msg02056.html

Murphy, Robert P. 2005. “But Wouldn't Warlords Take Over?” July 7; http://mises.org/story/1855

Murphy, Robert P. 2007 "The Fed's Role in the Housing Bubble." December 28; http://blog.mises.org/7590/the-feds-role-in-the-housing-bubble/

Murphy, Robert P. 2008A. "Consumers Don't Cause Recessions" November 11; http://mises.org/story/3194

Murphy, Robert P. 2008B. "An Open Letter to Gary Becker re: Depressions" November 24; http://mises.org/story/3220

Murphy, Robert P. 2008C. "Filling the Holes in Krugman's Analysis" January 15; http://mises.org/story/3291

Murphy, Robert P. 2008D. "The Importance of Capital Theory" October 20; http://mises.org/daily/3155

Murphy, Robert P. 2008E. "Did the Fed, or Asian Saving, Cause the Housing Bubble?" November 19; http://mises.org/daily/3203

Murphy, Robert P. 2009A. "Does "Depression Economics" Change the Rules?" January 12; http://mises.org/story/3290

Murphy, Robert P. 2009B. "Robert Lucas's Strange Faith in Bernanke” January 26; http:// mises.org/story/3305

Murphy, Robert P. 2009C. "Correcting Quiggin on Austrian Business-Cycle Theory" May 25; http://mises.org/story/3466

Murphy, Robert P. 2009D. Did Deregulated Derivatives Cause the Financial Crisis?

Murphy, Robert P. 2010A. "Putting Austrian Business Cycle Theory to the Test." October 18; http://mises.org/daily/4682

Murphy, Robert P. 2010B. "Did Hoover Really Slash Spending?" May 31; http://mises.org/daily/4350

Murphy, Robert P. 2010C. "The Economics of Libertarianism, Confused," July 12; http://mises.org/daily/4535

Newman, Simon. 1993. March 1939: The British Guarantee to Poland. Oxford: Oxford University Press

North, Gary. 1990. Tools of Dominion: The Case Laws of Exodus, Tyler, TX: Institute for Christian Economics.

North, Gary. 1992. The Coase Theorem, Tyler, Texas: Institute for Christian Economics

North, Gary. 2002. "Undermining Property Rights: Coase and Becker," The Journal of Libertarian Studies: An Interdisciplinary Review, Vol. 16, No. 4, Fall, pp. 75-100; http://www.mises.org/journals/jls/16_4/16_4_5.pdf 
Osterfeld, David. 1989. "Anarchism and the Public Goods Issue: Law, Courts and the Police," The Journal of Libertarian Studies, Vol. 9, No. 1, Winter, pp. 47-68; http://www.mises.org/journals/jls/9_1/9_1_3.pdf

Pasour, Jr., E.C., 1981, "The Free Rider as a Basis for Government Intervention," The Journal of Libertarian Studies, Vol. V, No. 4, Fall, pp. 453-464; http://www.mises.org/journals/jls/5_4/5_4_6.pdf

Paul, Ron, 2002. Testimony to U.S. House of Representatives, July 16; text of speech in Woods (2009, 16-17).

Paul, Ron. 2010. End the Fed. New York, N.Y.: Grand Central Publishing

Petro, Sylvester. 1957. The Labor Policy of the Free Society, New York: Ronald Press; http://www.amazon.com/exec/obidos/tg/detail/-/0471072133/lewrockwell/104$7552446-8407165$.

Polnar, Murray and Thomas E. Woods, eds. 2008. We Who Dared to Say No to War: American Antiwar Writing from 1812 to Now. New York, N.Y. Basic Books

Powell, Jim. 2005. Wilson's War: How Woodrow Wilson's Great Blunder Led to Hitler, Lenin, Stalin, and World War II. Crown Forum

Radosh, Ronald and Murray N. Rothbard, eds. 1972. A New History of Leviathan. New York: E. P. Dutton, http://mises.org/books/newhistoryleviathan.pdf

Raico, Ralph. 1998. "Review of the book Promised Land, Crusader State: The American Encounter with the World since 1776 by Walter A. McDougall, The Independent Review, Vol. III, No. 2, Fall, pp. 273-278.

Raj, Madhusudan. 2008. "Mending the Meltdown : Fending off the Interventions and Resurrecting the Market," The India Economy Review, December, pp. 38-44;

http://141.164.133.3/exchange/walterblock/Inbox/Re:\%20[mises] $\% 20$ please $\% 20$ he lp $\% 20$ on $\% 20$ ABCT $\% 20$ biblio.EML/1_multipart_xF8FF_2_Mending $\% 20$ The $\% 20 \mathrm{M}$ eltdown\%20-\%20Madhusudan\%20Raj.pdf/C58EA28C-18C0-4a97-9AF2-

036E93DDAFB3/Mending\%20The\%20Meltdown \%20-

$\% 20$ Madhusudan $\% 20$ Raj.pdf?attach $=1$

Reynolds, Morgan O. 1984. Power and Privilege: Labor Unions in America, New York: Manhattan Institute for Policy Research, 1984.

Reynolds, Morgan O. 1987, Making America Poorer: The Cost of Labor Law, Washington D.C.: Cato Institute

Reynolds, Morgan. 2009. "A History of Labor Unions from Colonial Times to 2009," July 17: http:// mises.org/daily/3553

Ritenour, Shawn R. 2000. "Postmodern Economics: The Return of Depression Economics by Paul Krugman," The Quarterly Journal of Austrian Economics, Vol. 3, No. 1: 79-83.

Robertson, Esmonde M., ed. 1971. The Origins of the Second World War. New York: St. Martins

Rockwell, Jr., Llewellyn H. 1998. "Vouchers: Enemy of Religion," [webpage] 1 September. [cited 12 May 2005]. $<$ http:/ $/$ www.mises.org/fullstory.aspx?control=106\&id $=79>$. 
Rockwell, Lew. 2000. "Education and the Election." http://www.lewrockwell.com/rockwell/educationandelection.html

Rockwell, Lew. 2002. "Vouchers: Another Name for Welfare. July 2. http://www.lewrockwell.com/rockwell/voucher2.html

Rogerson, Sidney. 1938. Propaganda in the Next War. London: Geoffrey Bles

Rome, Gregory and Walter Block. 2006. "Schoolhouse Socialism." Journal of Instructional Psychology, Vol. 33, No. 1, pp. 83-88; http://findarticles.com/p/ar ticles/mi_m0FCG/is_1_33/ai_n16118909/?tag=content;col1

Rosenberg, John S. 1972. "Toward A New Civil War Revisionism" in Gerald N. Grob and George Athan Bilias, eds., Interpretations of American History, I (New York: The Free Press, 1972), 459-479.

Rothbard, Murray N. (2004 [1962]). Man, Economy and State, Auburn AL: Ludwig von Mises Institute, Scholar's Edition; http://www.mises.org/rothbard/mes.asp

Rothbard, Murray N. [1963] 1975. America's Great Depression. Kansas City: Sheed and Ward, http://www.mises.org/rothbard/agd.pdf

Rothbard, Murray N. 1971. "Milton Friedman Unraveled." Individualist, February, pp. 3-7; http://www.lewrockwell.com/rothbard/rothbard43.html

Rothbard, Murray N. 1972A. "Review of The Literature of Isolationism A Guide To Non-Interventionist Scholarship, 1930-1972, by J. Doenecke. Books for Libertarians, December.

Rothbard, Murray N. 1972B. "War Collectivism in World War I." Ronald Radosh and Murray N. Rothbard (eds.), A New History of Leviathan. New York: E. P. Dutton, pp. 66-110.

Rothbard, Murray N. 1973. For a New Liberty, Macmillan, New York; http://www.mises.org/rothbard/newliberty.asp

Rothbard, Murray N. 1982. "Law, Property Rights, and Air Pollution." The Cato Journal, Vol. 2, No. 1, Spring, pp. 55-99. Reprinted in The Logic of Action Two: Applications and Criticism from the Austrian School. Glos, UK: Edward Elgar Publishing Ltd., 1997, pp. 121-170; http://www.mises.org/rothbard/lawproperty.pdf; reprinted in Economics and the Environment: A Reconciliation, Walter Block, ed., Vancouver: The Fraser Institute, 1990; http://mises.org/story/2120; http://www.mises.org/rothbard/lawproperty.pdf

Rothbard, Murray N. 1985. "Airport Congestion: A Case of Market Failure?" The Free Market. Auburn, AL: The Ludwig von Mises Institute, January, pp. 5-4.

Rothbard, Murray N. 1989. "World War I as Fulfillment: Power and the Intellectuals." The Journal of Libertarian Studies, Vol. 9, No. 1, Winter, pp. 81-125, http://mises.org/journals/jls/9_1/9_1_5.pdf; reprinted in The Costs of War, by J. V. Denson (ed.). New Brunswick, NJ: Transaction Publishers, 1998, pp. 203-254. Also appears in $2^{\text {nd }}$ Edition, 1999.

Rothbard, Murray N. 1993. Man, Economy and State, Auburn AL: Mises Institute; http://www.amazon.com/exec/obidos/tg/detail//0945466323/lewrockwell/104-7552446-8407165;

http://www.mises.org/rothbard/mes.asp 
Rothbard, Murray N. 1994. "Vouchers: What Went Wrong?" The Free Market. Auburn, AL: The Ludwig von Mises Institute, January, pp. 1, 8; http://mises.org/econsense/ch43.asp

Rothbard, Murray N. 1995. Making Economic Sense. Auburn, AL: Mises Institute. <http://www.mises.org./econsense/econsense.asp>: ch. 43.

Rothbard, Murray N. 1997. The Logic of Action: Applications and Criticism from the Austrian School, Vol. II, Cheltenham, UK: Edward Elgar

Rothbard, Murray N. 1998 [1982] The Ethics of Liberty, New York: New York University Press. http://www.mises.org/rothbard/ethics/ethics.asp

Salerno, Joseph T. 1989. "Comment on Tullock's 'Why Austrians Are Wrong About Depressions." Review of Austrian Economics 3: 141-145; http://mises.org/journals/rae/pdf/rae3_1_11.pdf

Salerno, Joseph T. 1996. "Why We Are Winning." Austrian Economics Newsletter, Fall , Volume 16, Number 3; http://mises.org/journals/aen/aen16_3_1.asp

Salerno, Joseph T. 1999. "Money and Gold in the 1920s and 1930s: An Austrian View"

Freeman, October, Volume, 49, Issue: 10;

http://www.thefreemanonline.org/featured/money-and-gold-in-the-1920s-and1930s-an-austrian-view/

Salerno, Joseph T. 2000. "Inflation and Money: A Reply to Timberlake," September 2000, Volume, 50, Issue: 9; http://www.thefreemanonline.org/featured/inflation-and-money-a-reply-totimberlake/

Salisbury, David F. 2003. "What Does a Voucher Buy? A Closer Look at the Cost of Private Schools." Cato Institute Policy Analysis, No. 486, August 28.

Samuelson, Paul A. 1967 (1970). Economics. $7^{\text {th }}$ ed. New York: McGraw-Hill

Schiff, Peter. Undated. http://www.google.com/\#sclient=psy\&hl=en\&rlz=1W1DMUS_en\&q=peter + schiff+economic + predictions\&rlz $=1$ W1DMUS_en\&aq $=3 \mathrm{~m} \& a q i=g 1 \mathrm{~g}-\mathrm{m} 3 \mathrm{~g}$ o1\&aql $=\mathrm{f} \&$ oq $=$ Schiff + econ\&gs_rfai $=\& \mathrm{pbx}=1 \& \mathrm{fp}=$ cadc6625497da7fb

Schmidt, Emerson P. 1973. Union Power and the Public Interest, Los Angeles, Nash

Schmidtz, David. 1991. The Limits of Government: An Essay on the Public Goods Argument, Boulder Co: Westview Press

Schroeder, Paul. 1958. The Axis Alliance and Japanese-American Relations, 1941. Ithaca, NY: Cornell University Press.

Schumpeter, Joseph A. 1942. Capitalism, Socialism and Democracy, New York: Harper

Sechrest, Larry. 1998. Review of Tyler Cowen's Risk and Business Cycles: New and Old Austrian Perspectives, Quarterly Journal of Austrian Economics, Fall 1998, Vol. 1, No. 3, 73-79; http://mises.org/journals/qjae/pdf/qjae1_3_9.pdf

Sechrest, Larry. 2003. "Privateering and National Defense: Naval Warfare for Private Profit", pages 239-74, The Myth of National Defense: Essays on the Theory and History of Security Production, edited by Hans-Hermann Hoppe, published by the Ludwig von Mises Institute, Auburn, Alabama, 2003. 
Sechrest, Larry. 2004A. "Public Goods and Private Solutions in Maritime History." The Quarterly Journal of Austrian Economics. Vol. 7, No. 2. Summer, 3-27; http://www.mises.org/journals/qjae/pdf/qjae7_2_1.pdf

Sechrest, Larry. 2004B "Private Provision of Public Goods: Theoretical Issues and Some Examples from Maritime History", ICFAI Journal of Public Finance, August 2004, Vol. II, No. 3, 45-73.

Sechrest, Larry. 2007. "Privately Funded and Built U.S. Warships in the QuasiWar of 1797-1801”, The Independent Review, Summer, Vol. 12, No. 1: 101-113.

Shea, Brian. 2010. "Solidarity Forever: The power invested in worker collectives under United States law." Journal of Libertarian Studies Vol. 22; pp. 219-246; http://mises.org/journals/jls/22_1/22_1_11.pdf

Schiff, Peter. Undated B.

http:/ / www.google.com.au/url?sa $=$ t\&source=web\&cd $=1 \&$ sqi $=2 \& v e d=0 C B g$ QtwIwAA\&url=http $\% 3 \mathrm{~A} \% 2 \mathrm{~F} \% 2 \mathrm{Fwww}$.youtube.com $\% 2 \mathrm{Fwatch} \% 3 \mathrm{Fv} \% 3 \mathrm{D} 2 \mathrm{I} 0 \mathrm{QN}$ FYkpw\&ei=_hrjTLziIY-yuAOhptCTDQ\&usg=AFQjCNHx7-0AWZCJ1qt-

zzk_mzCxd1N7TQ

Schiff, Peter. Undated C.

http:/ / www.google.com.au/url? sa $=$ t\&source $=$ web\&cd $=2 \&$ sqi $=2 \& v e d=0 C B 8$ QtwIwAQ\&url=http $\% 3 \mathrm{~A} \% 2 \mathrm{~F} \% 2 \mathrm{Fwww}$.youtube.com $\% 2 \mathrm{Fwatch} \% 3 \mathrm{Fv} \% 3 \mathrm{DZ} 0 \mathrm{YTY}$ 5TWtmU\&ei=_hrjTLziIY-

yuAOhptCTDQ\&usg=AFQjCNGdqTK_duwEQoSeeTpRDjKK6ZZxIw

Schiff, Peter. Undated D.

http:/ / www.google.com.au/url?sa $=$ t\&source $=$ web\&cd $=3 \&$ sqi $=2 \& v e d=0 C C Y$ QtwIwAg\&url=http $\% 3 \mathrm{~A} \% 2 \mathrm{~F} \% 2 \mathrm{Fwww}$.youtube.com $\% 2 \mathrm{Fwatch} \% 3 \mathrm{Fv} \% 3 \mathrm{DAq} 1 \mathrm{~N} 70$ vym1g\&ei=_hrjTLziIY-yuAOhptCTDQ\&usg=AFQjCNGT8D3w8JfPiljUJsJD-

HaztLAyOw

Schiff, Peter. 2006. Mortgage Bankers Speech to the Western Regional Mortgage Bankers Conference in Las Vegas; November 13;

http:/ /www.csaba.se/2009/09/26/peter-schiff-mortgage-bankers-speech-2006complete-transcript/

Schiff, Peter. 2007. Crash Proof: How to profit in the coming economic collapse (1st edition) New York, N.Y.: Wiley

Shostak, Frank. 2003. "Housing Bubble: Myth or Reality?" March 4; http: / / mises.org/article.aspx?control $=1177 \&$ titlenum $=\& F S=\&$ title $=\&$ Month

Shostak, Frank. 2005 "Is There a Glut of Saving?" August 4; http://mises.org/daily/1882

Shugart II, William F. 1987. "Don't Revise the Clayton Act, Scrap It!," 6 Cato Journal, 925

Skousen, Mark. 2001. "The Perseverance of Paul Samuelson's Economics." Forecasts \& Strategies. February 1; http://www.rosreferat.ru/economy/348.htm; http://www.mskousen.com/Books/Articles/perserverance.html

Smith, Jr., Fred L. 1983. "Why not Abolish Antitrust?," Regulation, Jan-Feb, 23

Snell, John L., ed. 1962. The Outbreak of the Second World War: Design or Blunder? Lexington, Mass.: D.C. Heath. 
Stringham, Edward Peter, and Mark White. 2004. "Economic Analysis of Tort Law: Austrian and Kantian Perspectives." In Law and Economics: Alternative Economic Approaches to Legal and Regulatory Issues, ed. Margaret Oppenheimer and Nicholas Mercuro, 374-392. New York: M.E. Sharpe. http://www.sjsu.edu/stringham/docs/Stringham.and.White2005.pdf

Stringham, Edward, ed. 2007. Anarchy and the Law: The Political Economy of Choice, Somerset, NJ: Transaction Publishers.

Stromberg, Joseph. 1979. "The War for Southern Independence: A Radical Libertarian Perspective," Journal of Libertarian Studies Vol. 3, No. 1, pp. 31-54; http://mises.org/journals/jls/3_1/3_1_3.pdf

Suvorov, Viktor. 1990. Icebreaker: Who Started the Second World War. New York: Viking.

Tannehill, Morris and Linda Tannehill. [1970] 1984. The Market for Liberty, New York: Laissez Faire Books; http://www.lewrockwell.com/orig11/tannehill1.html

Taylor, A.J.P. 1972. The First World War. London: Perigee Trade

Taylor, A.J.P. 1996 [1965]. The Origins of the Second World War. New York, NY: Simon \& Schuster

Terrell, Timothy D. 1999. "Property Rights and Externality: The Ethics of the Austrian School." Journal of Markets and Morality. Vol. 2, No. 2, Fall; http://www.acton.org/publications/mandm/mandm_article_114.php

Thornton, Mark and Robert B. Ekelund. 2004. Tariffs, Blockades, and Inflation: The Economics of the Civil War. Wilmington, Delaware: Scholarly Resources.

Thornton, Mark. 2004. "Housing: too good to be true." June 4; http://mises.org/daily/1533

Thornton, Mark. 2009. "The Economics of Housing Bubbles." America's Housing Crisis: A Case of Government Failure, Benjamin Powell and Randall Holcombe, eds., Transaction Publishers

Thornton, Mark. Undated. http://search.mises.org/search?access=p\&entqr=0\&output=xml_no_dtd\&s ort $=$ date $\% 3 A D \% 3 A L \% 3 A d 1 \& i e=U T F-$

$8 \&$ client $=$ default_frontend $\& \mathrm{q}=$ mark + thornton + housing + bubble $\& u d=1 \&$ site $=$ default_collection\&oe $=$ UTF-

$8 \&$ proxystylesheet $=$ default_frontend $\& \mathrm{ip}=68.186 .192 .60 \& \mathrm{start}=0$

Tinsley, Patrick. 1998-1999. "With Liberty and Justice for All: A Case for Private Police," Journal of Libertarian Studies, Vol. 14, No. 1, Winter, pp. 95-100; http://www.mises.org/journals/jls/14_1/14_1_5.pdf

Tolly, Kemp. 2002. Cruise of the Lanikai: To Provoke the Pacific War. Annapolis, MD: Naval Institute Press.

Tucker, Jeffrey. 1998A. "Controversy: Are Antitrust Laws Immoral?” Journal of Markets \& Morality. Vol. 1, No. 1, March, pp. 75-82; http://www.acton.org/publications/mandm/mandm_controversy_35.php

Tucker, Jeffrey. 1998B. "Controversy: Are Antitrust Laws Immoral? A Response to Kenneth G. Elzinga." Journal of Markets \& Morality. Vol. 1, No. 1, 
March,

pp.

90-94;

http://www.acton.org/publications/mandm/mandm_controversy_37.php

Utley, Jonathan. 1985. Going to War With Japan, 1937-1941. Knoxville: University of Tennessee

Vance, Laurence M. 1996. "Friedman's Mistake." The Free Market. Vol. 14, No. 11. November; http://mises.org/freemarket_detail.aspx?control=158

Woods, Thomas E. 2010. Nullification: How to Resist Federal Tyranny in the 21st Century. New York, NY: Regnery

Woods, Thomas E. Jr. 2009A. Meltdown: A Free-Market Look at Why the Stock Market Collapsed, the Economy Tanked, and Government Bailouts Will Make Things Worse. Washington D.C.: Regnery Publishing

Woods, Thomas E. Jr. 2009B. "Response to the 'Market Failure' Drones” June 10; http://mises.org/story/3503

Woods, Thomas E. Jr. 2009C. "Krugman Failure, Not Market Failure" June 19; http://www.lewrockwell.com/woods/woods116.html

Yates, Steven. 2002A. "Vouchers and Government Control." July 6; http://www.lewrockwell.com/yates/yates58.html

Yates, Steven. 2002B. "Refuting the Voucherites." July 13; http://www.lewrockwell.com/yates/yates59.html

Young, Andrew and Walter Block. 1999. "Enterprising Education: Doing Away with the Public School System," International Journal of V alue Based Management, Vol.12, No. 3, pp. 195-207; http://www.mises.org/etexts/enterprisingedu.pdf; http://www.mises.org/story/2216;

http://www.walterblock.com/publications/enterprising_education.pdf 